\title{
Glucagon-Like Peptide-1 Protects Human Islets against Cytokine-Mediated -Cell Dysfunction and Death: A Proteomic Study of the Pathways Involved
}

Rondas, Dieter; Bugliani, Marco; D’Hertog, Wannes; Hansen, Kasper Lage; Masini, Mathilde; Waelkens, Etienne; Marchetti, Piero; Mathieu, Chantal; Overbergh, Lut

Published in:

Journal of Proteome Research

Link to article, DOI:

$10.1021 /$ pr400527q

Publication date:

2013

Document Version

Publisher's PDF, also known as Version of record

Link back to DTU Orbit

Citation (APA):

Rondas, D., Bugliani, M., D’Hertog, W., Hansen, K. L., Masini, M., Waelkens, E., Marchetti, P., Mathieu, C., \& Overbergh, L. (2013). Glucagon-Like Peptide-1 Protects Human Islets against Cytokine-Mediated -Cell Dysfunction and Death: A Proteomic Study of the Pathways Involved. Journal of Proteome Research, 12(9), 204193-4206. https://doi.org/10.1021/pr400527q

\section{General rights}

Copyright and moral rights for the publications made accessible in the public portal are retained by the authors and/or other copyright owners and it is a condition of accessing publications that users recognise and abide by the legal requirements associated with these rights.

- Users may download and print one copy of any publication from the public portal for the purpose of private study or research.

- You may not further distribute the material or use it for any profit-making activity or commercial gain

- You may freely distribute the URL identifying the publication in the public portal 


\title{
porteome \\ pubs.acs.org/jpr research
}

\section{Glucagon-Like Peptide-1 Protects Human Islets against Cytokine-Mediated $\beta$-Cell Dysfunction and Death: A Proteomic Study of the Pathways Involved}

\author{
Dieter Rondas, ${ }^{\dagger}$ Marco Bugliani, ${ }^{\ddagger}$ Wannes D’Hertog, ${ }^{\dagger}$ Kasper Lage, ${ }^{\S, \|, \perp}$ Mathilde Masini, $^{\ddagger}$ \\ Etienne Waelkens, ${ }^{\#}$ Piero Marchetti, ${ }^{\ddagger}$ Chantal Mathieu, ${ }^{\dagger}, \nabla$ and Lut Overbergh ${ }^{*}, \dagger, \nabla$
}

${ }^{\dagger}$ Laboratory for Clinical and Experimental Endocrinology and ${ }^{\#}$ Laboratory of Protein Phosphorylation and Proteomics, KU Leuven, Herestraat 49, 3000 Leuven, Belgium

${ }^{\ddagger}$ Department Endocrinology and Metabolism, University of Pisa, via Paradisa 2, 56124 Pisa, Italy

${ }^{\S}$ Center for Biological Sequence Analysis, Technical University of Denmark, Kemitorvet Building 208, DK-2800 Lyngby, Denmark

"Pediatric Surgical Research Laboratories, MassGeneral Hospital for Children, Massachusetts General Hospital, 55 Fruit Street, Boston, Massachusetts 02114, United States

${ }^{\perp}$ Harvard Medical School, 25 Shattuck Street, Boston, Massachusetts 02115, United States

Supporting Information

ABSTRACT: Glucagon-like peptide-1 (GLP-1) has been shown to protect pancreatic $\beta$-cells against cytokine-induced dysfunction and destruction. The mechanisms through which GLP-1 exerts its effects are complex and still poorly understood. The aim of this study was to analyze the protein expression profiles of human islets of Langerhans treated with cytokines (IL- $1 \beta$ and IFN- $\gamma$ ) in the presence or absence of GLP-1 by $2 \mathrm{D}$ difference gel electrophoresis and subsequent protein interaction network analysis to understand the molecular pathways involved in GLP-1-mediated $\beta$-cell protection. Co-incubation of cytokine-treated human islets with GLP-1 resulted in a marked protection of $\beta$-cells against cytokine-induced apoptosis and significantly attenuated cytokine-mediated inhibition of glucose-stimulated insulin secretion. The cytoprotective effects of GLP-1 coincided with substantial alterations in the protein expression profile of cytokine-treated human islets, illustrating a counteracting effect on proteins from different functional classes such as actin cytoskeleton, chaperones,

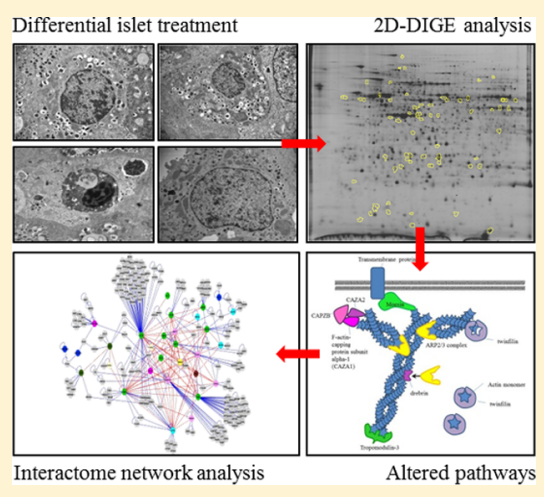
metabolic proteins, and islet regenerating proteins. In summary, GLP-1 alters in an integrated manner protein networks in cytokine-exposed human islets while protecting them against cytokine-mediated cell death and dysfunction. These data illustrate the beneficial effects of GLP-1 on human islets under immune attack, leading to a better understanding of the underlying mechanisms involved, a prerequisite for improving therapies for diabetic patients.

KEYWORDS: GLP-1, Type 1 diabetes, human islets, cytokines, 2D-DIGE, protein interaction networks

\section{INTRODUCTION}

Pro-inflammatory cytokines such as IL- $1 \beta$, IFN- $\gamma$, and TNF- $\alpha$ have been implicated as important mediators of $\beta$-cell dysfunction and destruction in type- 1 diabetes and type- 2 diabetes. ${ }^{1-3}$ The detrimental effect of these cytokines on $\beta$-cell function and survival is mediated via a complex network of cytokine-responsive genes. ${ }^{4}$ Central in this regulation are intracellular signaling factors, including nuclear factor $\kappa \mathrm{B}(\mathrm{NF}-\kappa \mathrm{B})$ and signal transducer and activator of transcription 1 (STAT1). ${ }^{5,6}$ In addition, pro-inflammatory cytokines have also been shown to induce $\beta$-cell apoptosis by mediating endoplasmic reticulum (ER) $\mathrm{Ca}^{2+}$ depletion, resulting in ER stress. ${ }^{7}$

Glucagon-like peptide 1 (GLP-1) is a 30 -amino acid incretin hormone that is secreted from intestinal $\mathrm{L}$ cells, pancreatic $\alpha$ cells, and the caudal brain stem in a regulated manner. ${ }^{8}$ By means of its regulatory actions on both pancreatic islets and peripheral tissues, GLP-1 contributes to metabolic adaptation to meal ingestion and overall glucose homeostasis. ${ }^{9}$ Moreover, GLP-1 not only enhances the glucose sensing and insulin secretory capacity of pancreatic islets ${ }^{10}$ but also inhibits $\beta$-cell apoptosis and stimulates $\beta$-cell proliferation and islet neogenesis, thereby enhancing $\beta$-cell mass. ${ }^{11}$ Many of these effects are exerted by GLP-1-induced activation of adenylyl cyclase, which leads to increased intracellular cAMP concentrations. Downstream signaling is, among others, mediated by the phosphatidylinositol 3-kinase (PI3K)-protein kinase B (PKB)/ Akt pathway, the PKA pathway, and cAMP response elementbinding (CREB) protein. ${ }^{12-14}$ Furthermore, GLP-1 also controls glycaemia by inhibiting glucagon secretion and suppressing hepatic glucose output as well as by decreasing the rate of gastric emptying. ${ }^{15}$ Injectable GLP-1 receptor

Received: June 5, 2013

Published: August 12, 2013 
agonists and oral inhibitors of the natural enzyme degrading GLP-1, dipeptidylpeptidase 4 (DPP-4), are currently widely used as glucose-lowering agents in type- 2 diabetes patients. ${ }^{16}$

The molecular mechanisms by which cytokines affect $\beta$-cell function and survival and by which GLP-1 may protect against this inflammatory attack are still marginally understood. Here, as a follow-up of previous studies by D'Hertog et al. ${ }^{17}$ and Tews et al., ${ }^{18}$ proteome analysis of human islets was performed using 2D difference gel electrophoresis (2D-DIGE) combined with protein interaction network analysis. This increases our understanding of the mechanisms involved in these processes because the current knowledge is largely based on RNA-based studies, ${ }^{19-25}$ while many forms of regulation take place at a post-transcriptional level, such as post-translational modifications (PTMs) and proteolytic degradation. Most importantly, these are also picked up with this protein-based approach. ${ }^{26}$

We identified several cytokine- and/or GLP-1-responsive proteins from different functional classes indicating major changes in actin cytoskeleton (re)organization, metabolism, chaperones, and islet-regenerating proteins and revealed complex interactions between these pathways. Understanding the cross-talks and identifying molecular targets involved in cytokine-induced $\beta$-cell dysfunction and destruction and the beneficial effects of GLP-1 thereon thus increases our understanding of the physiological and pharmacological effects of GLP-1, a prerequisite when attempting effective therapeutic interventions for patients with type- 1 and type- 2 diabetes.

\section{METHODS}

\section{Human Islet Isolation}

Islets were isolated by enzymatic digestion and gradient purification $^{27,28}$ from pancreata of 14 multiorgan donors (age: $60 \pm$ 17 years; male/female ratio: 6/8; BMI: $\left.24.9 \pm 4.2 \mathrm{~kg} / \mathrm{m}^{2}\right)$ and cultured in M199 medium containing $5.5 \mathrm{mmol} / \mathrm{L}$ glucose, supplemented with $10 \%$ (vol/vol) serum, $100 \mathrm{U} / \mathrm{mL}$ penicillin, $100 \mu \mathrm{g} / \mathrm{mL}$ streptomycin, $50 \mu \mathrm{g} / \mathrm{mL}$ gentamicin, and $750 \mathrm{ng} / \mathrm{mL}$ amphotericin B (Sigma-Aldrich, St. Louis, MO). ${ }^{27,28} 1000$ islets were incubated for $72 \mathrm{~h}$ either with or without $50 \mathrm{U} / \mathrm{mL}$ IL- $1 \beta$ plus $1000 \mathrm{U} / \mathrm{mL}$ IFN- $\gamma$ (Roche Diagnostics, Milan, Italy) and with or without $10 \mathrm{nmol} / \mathrm{L}$ GLP-1 (Sigma-Aldrich, Milan, Italy). The latter was replenished every $12 \mathrm{~h}$.

\section{Insulin Secretion Analysis}

For insulin secretion studies, which were performed as previously described, ${ }^{29,30}$ islets were first kept at $37{ }^{\circ} \mathrm{C}$ for $45 \mathrm{~min}$ in Krebs-Ringer bicarbonate (KRB), 0.5\% ( $\mathrm{vol} / \mathrm{vol}$ ) albumin, $\mathrm{pH}$ 7.4, containing $3.3 \mathrm{mmol} / \mathrm{L}$ glucose (wash-out phase). Then, the medium was replaced with KRB containing $3.3 \mathrm{mmol} / \mathrm{L}$ glucose to assess basal insulin secretion $(45 \mathrm{~min})$, followed by a further $45 \mathrm{~min}$ incubation with $16.7 \mathrm{mmol} / \mathrm{L}$ glucose to assess insulin response to acute challenge. Insulin was quantified by RIA (Pantec Forniture Biomediche, Turin, Italy), and insulin secretion is expressed as a stimulation index, corresponding to the ratio between stimulated $(16.7 \mathrm{mmol} / \mathrm{L}$ glucose) and basal $(3.3 \mathrm{mmol} / \mathrm{L}$ glucose $)$ insulin secretion.

\section{Cell Death Analysis}

Electron microscopy studies were performed at the end of the previously described incubation conditions according to the procedures previously described. ${ }^{29,30}$ Cells were considered dead on the basis of the following criteria: loss of plasma membrane integrity, fragmentation into discrete bodies, engulfment of cell corpse, or its fragments by an adjacent cell. The presence of marked chromatin condensation or blebs was considered to be a sign of apoptosis. For morphometric studies, 25 micrographs, obtained at $\times 10000$, were analyzed by overlay with a graticule $(11 \times 11 \mathrm{~cm})$ composed of 169 points. For the study of insulin granules and mitochondria, volume density (VD), expressed as $\mathrm{mL} / 100 \mathrm{~mL}$ tissue ( $\mathrm{mL} \%$ ), was calculated according to the formula: $\mathrm{VD}=\mathrm{Pi} / \mathrm{Pt}$, where $\mathrm{Pi}$ is the number of points within the subcellular component and $\mathrm{Pt}$ is the total number of points. $30-40 \beta$-cells per islet, obtained from three different islet preparations, were analyzed per condition.

\section{D-DIGE Analysis}

Quadruplicate experiments were performed using islets from four individual islet preparations. As for the experimental setup, we analyzed four different conditions, that is, control $(n=4)$, GLP-1 $(n=4)$, IL- $1 \beta+\operatorname{IFN} \gamma(n=4)$, and the combination of IL- $1 \beta+$ IFN $\gamma$ with GLP-1 $(n=4)$. This resulted in a total of 16 samples, which were randomly run on 8 separate gels, assuring that for each condition two "forward" gels ( $\mathrm{Cy} 3$ labeled) and two "reverse" gels ( $\mathrm{Cy} 5$ labeled) were run. In addition, each gel contained a pooled internal standard labeled with Cy2. For each condition, 1000 human islets were treated as previously described and collected and processed as follows. Islets were washed twice in PBS and resuspended in $50 \mu \mathrm{L}$ of $2 \mathrm{D}$-DIGE lysis buffer ( $7 \mathrm{~mol} / \mathrm{L}$ urea; $2 \mathrm{M}$ thiourea; $4 \%(\mathrm{w} / \mathrm{v})$ CHAPS; $40 \mathrm{mM}$ Trisbase; $1 \%(\mathrm{w} / \mathrm{v}) \mathrm{DTT}$; and a mixture of protease inhibitors (Complete Protease Inhibitor, Roche Diagnostics, Basel, Switzerland)). Samples were sonicated (five times $10 \mathrm{~s}$ on ice, with an interval of $20 \mathrm{~s}$ on ice) and centrifuged for $15 \mathrm{~min}$ at $21000 \mathrm{~g}$ and $4{ }^{\circ} \mathrm{C}$ to remove cell debris. The supernatant was desalted by dialysis (PlusOne Mini Dialysis kit, GE Healthcare, Diegem, Belgium). $50 \mu \mathrm{g}$ protein sample was labeled with 200 pmol $\mathrm{Cy} 3$ or $\mathrm{Cy} 5$, while $50 \mu \mathrm{g}$ of pooled internal standard was labeled with 200 pmol Cy2. The internal standard consisted of a pool of all control and treated samples of all four replicate experiments. Labeling was performed according to manufacturer's instructions (GE Healthcare). Labeled protein extracts were pooled, and sample loading buffer was added (7 M Urea; $2 \mathrm{M}$ Thiourea; 4\% (w/v) CHAPS; 0.5\% (v/v) IPG buffer; and $1 \%(\mathrm{w} / \mathrm{v}) \mathrm{DTT})$. Protein samples were separated in the first dimension using the $\mathrm{pH}$ range $4-7$ on 24 $\mathrm{cm}$ IPG strips (GE Healthcare). Therefore, IPG strips were rehydrated overnight with rehydration buffer (7 M urea, $2 \mathrm{M}$ thiourea, 4\% (w/v) CHAPS, 0.5\% (v/v) IPG buffer, 0.05\% (w/v) OrangeG, and $1 \%(\mathrm{w} / \mathrm{v}) \mathrm{DTT})$. The first dimension separation was tracked using the Ettan IPGphor control software (version 1.01.03) (GE Healthcare) and was ended when the current reached a stable phase (at $\sim 60 \mathrm{kV}-\mathrm{h}$ ). Next, the strips were equilibrated for two times $15 \mathrm{~min}$ in an equilibration buffer (6 M urea, 30\% (v/v) glycerol, 2\% (w/v) SDS, and $50 \mathrm{mM}$ Tris$\mathrm{HCl}, \mathrm{pH} 8.8)$ containing $1 \%(\mathrm{w} / \mathrm{v})$ DTT in the first step and $4 \%(\mathrm{w} / \mathrm{v})$ iodoacetamide and $0.02 \%$ bromphenol blue in the second step. Equilibrated strips were then separated on a $12.5 \%$ SDS-polyacrylamide gel in the second dimension on an Ettan DaltSix system (GE Healthcare) at $8 \mathrm{~mA} /$ gel, $9 \mathrm{~W}$, and $600 \mathrm{~V}$ for $1 \mathrm{~h}$ and then at $16 \mathrm{~mA} /$ gel, $15 \mathrm{~W}$, and $600 \mathrm{~V}$ until the bromophenol blue dye front reached the bottom of the gel. The gels were scanned using a Typhoon 9400 (GE Healthcare). Initial scan parameters were press sample, depth plus $3 \mathrm{~mm}$, 500 to $550 \mathrm{~V}$ photomultiplier tube setting, and $1000 \mu \mathrm{m}$ pixel size before repeating at $100 \mu \mathrm{m}$ pixel size for a high-resolution scan. Spot detection and matching was performed automatically 
using the BVA module of DeCyder version 7.0 software, followed by careful manual rematching of wrongly matched spots or unmatched spots. Spot detection parameters were set as described by the manufacturer: spot detection algorithm 6.0, estimated number of spots 10000 . The eight internal standards from the eight gels were used to calculate average abundance. For the analysis, we compared control $(n=4)$ versus IL- $1 \beta+$ IFN- $\gamma(n=4)$, control $(n=4)$ versus GLP-1 $(n=4)$, and $\mathrm{IL}-1 \beta+\operatorname{IFN}-\gamma(n=4)$ versus IL- $1 \beta+\operatorname{IFN}-\gamma+\operatorname{GLP}-1(n=4)$. Protein spot expression levels that showed a statistically significant $(P<0.05)$ increase or decrease in six out of eight (Cy3 or Cy5 labeled) gels were accepted as being differentially expressed.

\section{Spot Digestion and Protein Identification}

For spot picking, four preparative gels were run $(250 \mu \mathrm{g}$ protein lysate each). First and second dimension runs were performed as described above, except that Cy dye-labeling was omitted. Glass plates $(27 \times 21 \mathrm{~cm})$ were pretreated with BindSilane, and two reference markers were applied to enable automatic picking. The gels $(24 \times 20 \mathrm{~cm})$ were poststained using Krypton (Pierce). Matching with the analytical gels was performed using the BVA module of the DeCyder V7.0 software. A pick list was generated and exported into the Spot Picker V1.20 software, which controls the Ettan Spot Picker (GE Healthcare). Spots were picked in Milli-Q water and rinsed three times with Milli$\mathrm{Q}$ water and three times with acetonitrile (LC-MS quality, CHROMASOLV, Sigma-Aldrich). Next, the gels were hydrated in $100 \mathrm{mM}$ ammonium bicarbonate for $10 \mathrm{~min}$, followed by a dehydration step in $100 \%$ acetonitrile for $10 \mathrm{~min}$ with vigorous vortexing. This step was repeated twice prior to dehydrating the gel pieces in a SpeedVac. Gel pieces were then rehydrated in digestion buffer $(50 \mathrm{mM}$ ammonium bicarbonate and $5 \mathrm{mM}$ calcium chloride) containing $5 \mathrm{ng} / \mu \mathrm{L}$ modified trypsin (Promega, Madison, WI) and incubated overnight at $37^{\circ} \mathrm{C}$. The resulting peptides were extracted out of the gel plugs in four steps: once with $50 \mathrm{mM}$ ammonium bicarbonate, twice with $50 \%(\mathrm{v} / \mathrm{v})$ acetonitrile and $5 \%(\mathrm{v} / \mathrm{v})$ formic acid, and once with $95 \%$ acetonitrile and $5 \%$ formic acid (30 min each). Supernatants were dried in a SpeedVac. Samples were concentrated and desalted using Millipore C18 ZipTips. The peptides were eluted in $10 \mu \mathrm{L}$ of $70 \%$ acetonitrile and $0.1 \%$ formic acid and dried in a SpeedVac. Samples were dissolved in $1 \mu \mathrm{L}$ of $\alpha$-cyano-4hydroxycinnamic acid matrix (saturated solution in 50\% acetonitrile and $0.1 \%$ trifluoroacetic acid in HPLC water), spotted onto the MALDI target plate, and allowed to air-dry.

MS/MS analyses were performed on a 4800 MALDI TOF/ TOF (Applied Biosystems, Carlsbad, CA). The instrument was calibrated with the Applied Biosystems Calibration Mixture 1. The mass accuracy (external calibration) was $<50 \mathrm{ppm}$ in reflection mode. Measurements were taken in the positive ion mode between 900 and $3000 \mathrm{~m} / z$. Sequences were automatically acquired by scanning first in MS mode and selecting the 15 most intense ions for MS/MS using an exclusion list of peaks arising from tryptic autodigestion. Air was used as the collision gas, while the collision energy was adapted automatically. Data interpretation was carried out using the GPS Explorer software (V3.6), and database searching was carried out using the Mascot program (version 2.2.00). Because all experiments were performed on human islets, searches were conducted in the following database: UniProt_sprot (517 100 sequences; 182146551 residues, release date June 2010) with the taxonomy set on Homo sapiens (20 367 sequences) using the MS/MS data. Mass tolerance for precursor ions (peptide tolerance) was set on $50 \mathrm{ppm}$, and on $0.4 \mathrm{Da}$ for fragment ions (MS/MS tolerance) methionine oxidation was selected as variable modification and carbamidomethylation of cysteine was selected as fixed modification. Trypsin was selected as enzyme and a maximum of one missed cleavage was allowed. Using these parameters, the probability-based MOWSE scores greater than the given cutoff value for MS/MS fragmentation data were taken as significant $(p<0.05)$. Moreover, the individual scores of the individual identified peptides were scrutinized for their individual $p$ value. Peptides with a $p$ value $>0.05$ were omitted, and the total score was recalculated as the sum of the scores of the individual peptides with a $p$ value $<0.05$ (Suppl. Tables $1-3$ in the Supporting Information). All additional mass spectrometric information of the individual peptide sequences are also provided in Suppl. Tables 1-3 in the Supporting Information. We excluded the identifications that were based on single peptides, and in the remaining cases where more than one protein could be detected per spot we classified the multiple identifications with an identical differential expression.

\section{Western Blot Analysis}

Human islets were lysed in 2D-DIGE lysis buffer for $15 \mathrm{~min}$ on ice. Total cell lysate was sonicated and centrifuged ( $15 \mathrm{~min}$ at $21000 \mathrm{~g}$ and $4{ }^{\circ} \mathrm{C}$ ), and afterward the supernatant was used for Western blot analysis. The protein samples were separated on 4-12\% BT gels (Invitrogen), blotted onto a PVDF membrane (Hybond-ECL; GE Healthcare), and probed with goat antiREG1A (1:100), rabbit anti-REG1B (1:500), and goat antiTRPRS (1:500) (Santa Cruz Biotechnology, Santa Cruz, CA) and mouse anti-GAPDH $(1: 10,000)$ (Life Technologies, Ghent, Belgium) as primary antibodies. The secondary antibodies (1:5000), rabbit antigoat, goat antirabbit, and rabbit antimouse, were from Dako. Western blots were incubated with the Western lightning Plus-ECL detection system (PerkinElmer) and exposed to Amersham Hyperfilm ECL-films (GE Healthcare).

\section{Network Analyses}

Data were downloaded from MINT 48, BIND 49, IntAct 50, KEGG, and Reactome. To increase the coverage of interactions, interolog data 53 (the transfer of protein interactions between orthologous protein pairs in different organisms) were included. Interactions from 17 eukaryotic organisms were transferred and added to the network. Orthology was assigned using the Inparanoid database 55 using stringent thresholds. The statistical significance of the networks was estimated using a randomization scheme in which networks were generated from random input sets of the same size as in the present experiment. We performed 10000 randomizations from which we derived a probability distribution that was used to calculate the significance of the networks in this study.

\section{Statistical Analysis}

All data are presented as means \pm SEM. For all experiments, unless stated differently, comparisons were performed by twotailed unpaired $t$ test. A $p$-value $<0.05$ was considered statistically significant.

\section{RESULTS}

GLP-1 Counteracts the Inhibitory Effect of Cytokines on Glucose-Stimulated Insulin Secretion and Protects Human Islet $\boldsymbol{\beta}$-Cells against Cytokine-Induced Apoptosis

To assess the effect of GLP-1 on cytokine-mediated $\beta$-cell dysfunction and destruction, we incubated human islets 
Table 1. Effect of Cytokines and GLP-1 on Glucose-Stimulated Insulin Secretion and Insulin Granule Density in Human Islets

$\begin{array}{lcccc} & \begin{array}{c}\text { insulin at } 3.3 \mathrm{mmol} / \mathrm{L} \\ \text { glucose }(\mu \mathrm{U} / \text { islet/min })^{a}\end{array} & \begin{array}{c}\text { insulin at } 16.7 \mathrm{mmol} / \mathrm{L} \\ \text { glucose }(\mu \mathrm{U} / \text { islet/min })^{a}\end{array} & \begin{array}{c}\text { stimulation } \\ \text { index }\end{array} & \begin{array}{c}\text { stimulation index } \\ (\% \text { from control })\end{array} \\ \text { control } & 0.032 \pm 0.004 & 0.107 \pm 0.03 & 3.2 \pm 0.6 & 100 \\ \text { insulin granule }(\text { volume density, mL\% })^{b}\end{array}$

${ }^{a}$ Data from six different islet preparations. ${ }^{b}$ Data from 30 to $40 \beta$-cells for each different experimental condition. The stimulation index was calculated by dividing the measured insulin values from the $16.7 \mathrm{mmol} / \mathrm{L}$ glucose samples by the insulin values from the $3.3 \mathrm{mmol} / \mathrm{L}$ glucose samples. ${ }^{c} p<0.05$ vs all other groups after Bonferroni correction. ${ }^{d} p<0.05$ vs control and GLP-1 after Bonferroni correction.

for $72 \mathrm{~h}$ with or without IL- $1 \beta$ and IFN- $\gamma$, combined with GLP1 or its vehicle. Insulin release $(\mu \mathrm{U} /$ islet $/ \mathrm{min})$ from control islets was $0.032 \pm 0.004$ at $3.3 \mathrm{mmol} / \mathrm{L}$ glucose and increased to $0.107 \pm 0.03$ at $16.7 \mathrm{mmol} / \mathrm{L}$ glucose (Table 1 ). We observed no significant changes in glucose responsiveness upon incubation with GLP-1 alone. Cytokine treatment was associated with reduced glucose-stimulated insulin secretion (GSIS), which was prevented upon coincubation with GLP-1 (Table 1). This was accompanied by a reduction in insulin
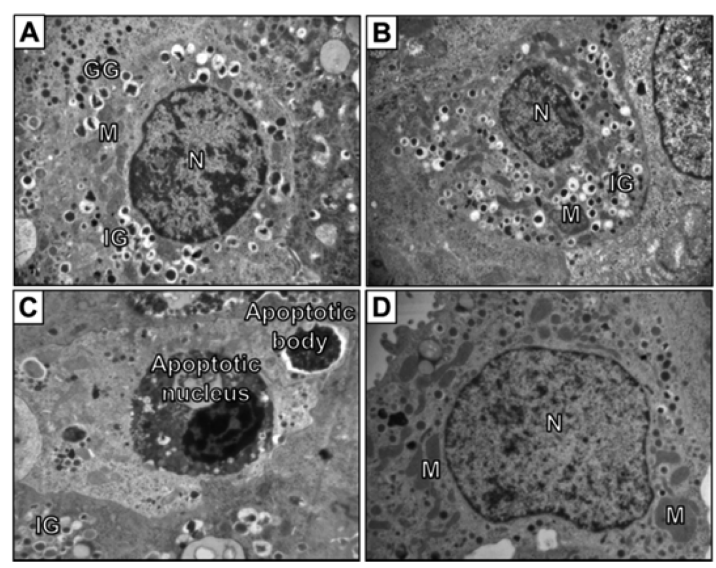

Figure 1. Effect of cytokines and/or GLP-1 on human islet function and destruction. Representative micrographs of (A) control, (B) GLP1 -treated, (C) IL- $1 \beta$ - and IFN- $\gamma$-treated, and (D) IL- $1 \beta$-, IFN- $\gamma$-, and GLP-1-treated pancreatic islets. IG, insulin granules; GG, glucagon granules; M, mitochondrion; $\mathrm{N}$, nucleus (magnifications: $\times 10000$ ).

granule density in cytokine-treated islets, which was not corrected by GLP-1 (Table 1 and Figure 1). Mitochondrial VD increased significantly after cytokine treatment from $3.1 \pm 0.2$ to $5.4 \pm 0.9 \mathrm{~mL} \%(p<0.05)$, indicating cytokine-induced early stage apoptosis (Table 2 and Figure 1). Co-incubation with GLP-1 resulted in a mitochondrial VD of $3.9 \pm 0.3 \mathrm{~mL} \%$, corresponding to a partial inhibition of the observed cytokine effect. As for $\beta$-cell apoptosis, cytokine exposure induced a significant increase in the percentage of apoptotic $\beta$-cells from 1 \pm 0.6 to $18 \pm 3.5 \%(p<0.005)$, an effect that was almost completely prevented by coincubation with GLP-1 (Table 2).

Cytokine-Induced Alterations in Human Islet Protein Expression: 2D-DIGE and Protein Identifications

Next, proteomic profiles of control and cytokine-treated islets were determined using 2D-DIGE, revealing 58 differentially expressed spots $(p<0.05)$ (Suppl. Figure 1 in the Supporting Information), of which 45 could unambiguously be identified by MALDI-TOF/TOF (identification rate of $75 \%$ ). On the basis of literature searching, the identified proteins were grouped in the same functional classes, as were used in previous
Table 2. Effect of Cytokines and GLP-1 on $\beta$-Cell Apoptosis and Morphology of Mitochondria in Human Islets ${ }^{a}$

\begin{tabular}{lcc} 
& $\begin{array}{c}\text { apoptosis } \\
(\%)\end{array}$ & mitochondria (volume density, mL\%) \\
& $1 \pm 0.6$ & $3.1 \pm 0.2$ \\
control & $1 \pm 0.6$ & $3.5 \pm 0.3$ \\
GLP-1 & $18 \pm 3.5^{b}$ & $5.4 \pm 0.9^{b}$ \\
cytokines & $4 \pm 1.2$ & $3.9 \pm 0.3$ \\
cytokines + GLP-1 & \\
ay Data from three different islet preparations. ${ }^{b} p<0.05$ vs all other \\
groups after Bonferroni correction. \\
\hline
\end{tabular}

microarray ${ }^{22}$ and proteome ${ }^{17}$ analyses. Table 3 illustrates the complete list of identified cytokine-modified proteins grouped according to their function and includes information on the UniProt accession number, fold regulation, and number of identified peptides above identity threshold. Additional information is provided in Suppl. Table 1 in the Supporting Information.

\section{Cytokine Effect on Metabolic Proteins}

Cytokine treatment of human islets induced a significant downregulation of five different proteins involved in the mitochondrial respiratory chain (ATP synthase subunit beta and $\mathrm{NADH}$ dehydrogenase (ubiquinone) iron-sulfur protein 3 ), the Krebs cycle (succinyl-CoA ligase (GDP-forming) subunit beta), alcohol metabolism (mitochondrial aldehyde dehydrogenase), and ganglioside degradation (beta-hexosaminidase subunit alpha). In addition to these down-regulated proteins, we also observed a significant cytokine-induced up-regulation of cytoplasmic malate dehydrogenase, a protein involved in the malate-aspartate shuttle.

\section{Cytokine Effect on Protein Synthesis, Folding, and Modification}

Treatment of human islets with IL- $1 \beta / \mathrm{IFN}-\gamma$ resulted in a major, almost six-fold, down-regulation of the activator of $90 \mathrm{kDa}$ heat shock protein ATPase homologue 1, which is a chaperone that stimulates HSP90 ATPase activity and may be involved in ER to Golgi trafficking. Furthermore, cytokine treatment also resulted in a marked decrease in expression of eukaryotic initiation factor 4A-I and II, both known to be required for mRNA binding to ribosomes. Also note that three down-regulated spots were found that contain two or more chaperones, which makes it difficult to conclude which of the chaperones, if not all, are actually decreased upon cytokine treatment.

\section{Cytokine Effect on Protein Degradation}

Considering proteins involved in the regulation of protein degradation, we observed a significant, cytokine-mediated downregulation of two isoforms of the pancreatic exopeptidase carboxypeptidase A1. Moreover, cytokine treatment also resulted in a clear up-regulation of the glycoprotein alpha-1-antichymotrypsin and 
Table 3. Identification of Proteins with an Altered Expression Profile upon IL-1 $\beta$ and IFN- $\gamma$ Treatment of Human Islets Compared with Controls

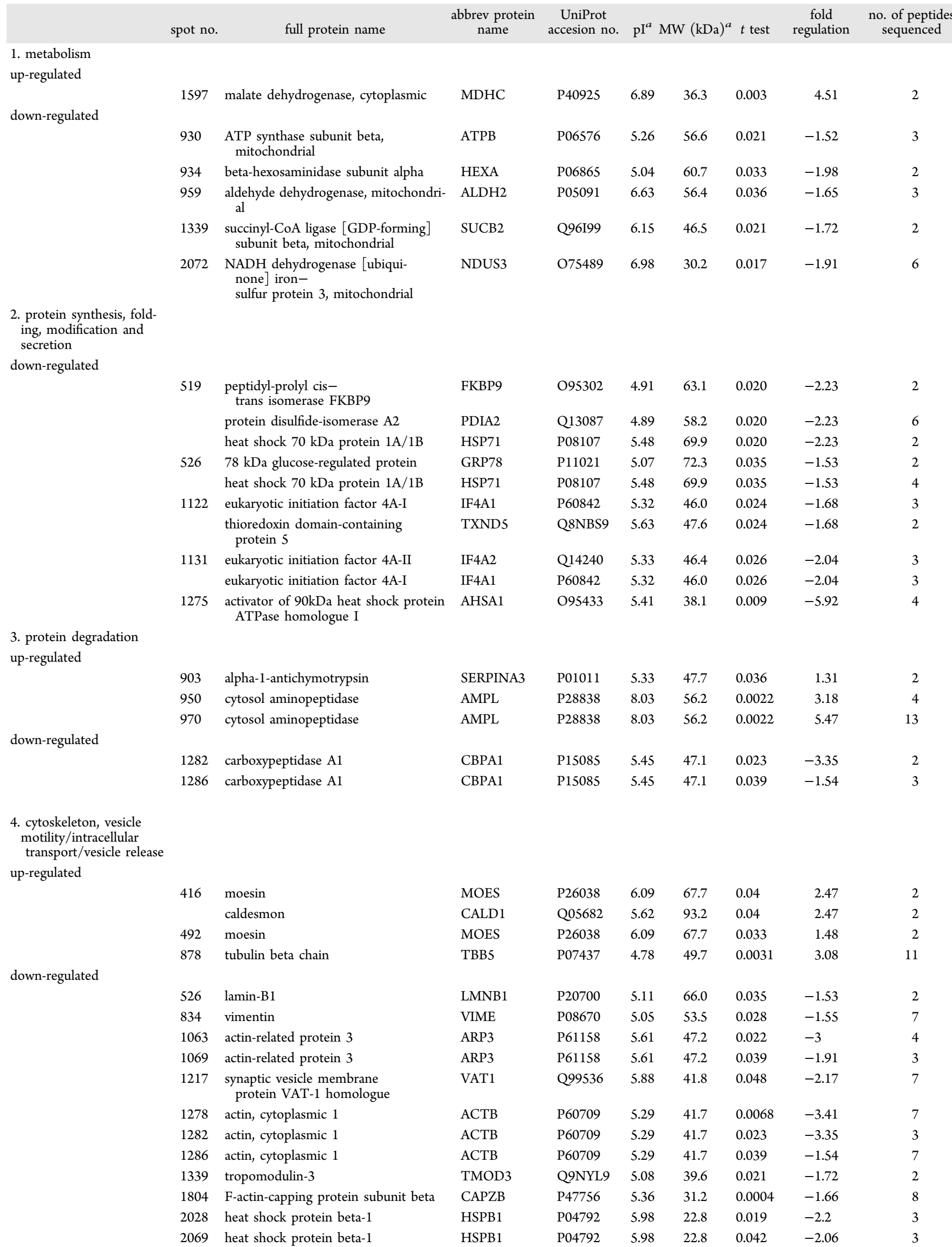


Table 3. continued

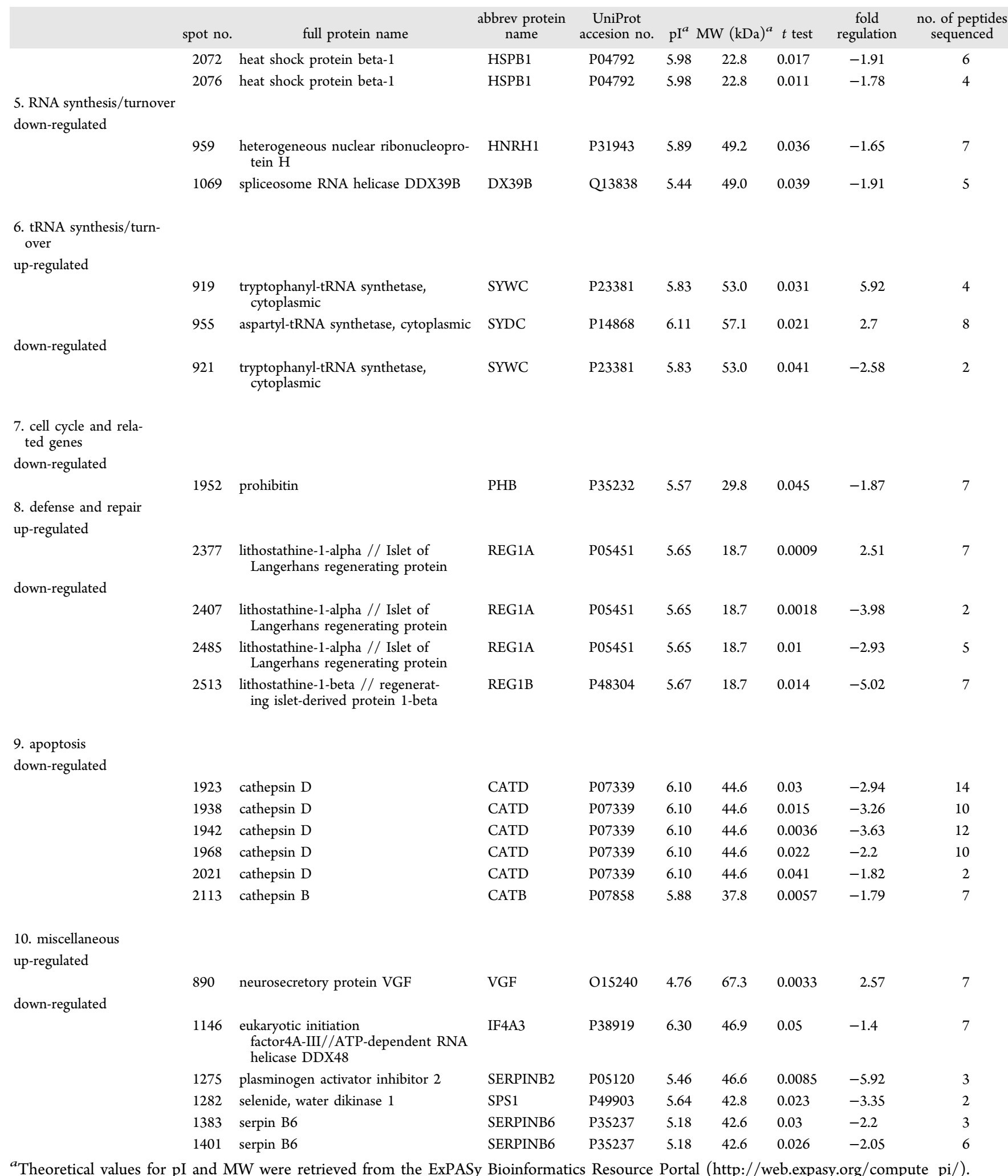

two cytosol aminopeptidase isoforms, which are known to be involved in the processing and regular turnover of intracellular proteins. Cytokine Effect on Cytoskeleton and Vesicle Motility

Among all of the protein alterations observed, cytokine exposure of human islets had the most dramatic effect on the group of proteins involved in cytoskeleton organization and vesicle motility. Here several proteins involved in actin (de)polymerization ( $\beta$-actin, actin-related protein 3 , tropomodulin-3, F-actin-capping protein subunit beta, and heat shock protein beta-1) were significantly down-regulated. Furthermore, we observed an up-regulation of tubulin $\beta$-chain TBB5 - a major component of microtubules, caldesmon - a calmodulinand actin-binding protein known to regulate ATPase activity of 
myosin and two isoforms of moesin that functions as a crosslinker between the plasma membrane and actin-based cytoskeleton. These data, together with the observed downregulation of the intermediate filament protein vimentin, indicate that cytokine treatment of human islets interferes with the three major components of the cytoskeleton, namely, the actin-based microfilaments, the tubulin-based microtubules, and the intermediate filaments. Finally, also the synaptic vesicle membrane protein VAT-1 homologue, known to be involved in vesicular transport and lamin B1, were found down-regulated upon cytokine treatment. The latter may be associated with the observed increased apoptosis rate because disassembly of lamin B1 represents one of the various features of apoptotic cells.

\section{Cytokine Effect on Defense and Repair}

In the functional group of proteins involved in cellular defense and repair, both REG1A and REG1B, known to be involved in $\beta$-cell proliferation and neogenesis, ${ }^{31}$ were altered upon cytokine treatment. As for REG1A, one isoform was upregulated, whereas two other isoforms were significantly downregulated by cytokine exposure of the islets. On the basis of the position of the three isoforms on the $2 \mathrm{D}$ gel (Figure $2 \mathrm{~A}$ and

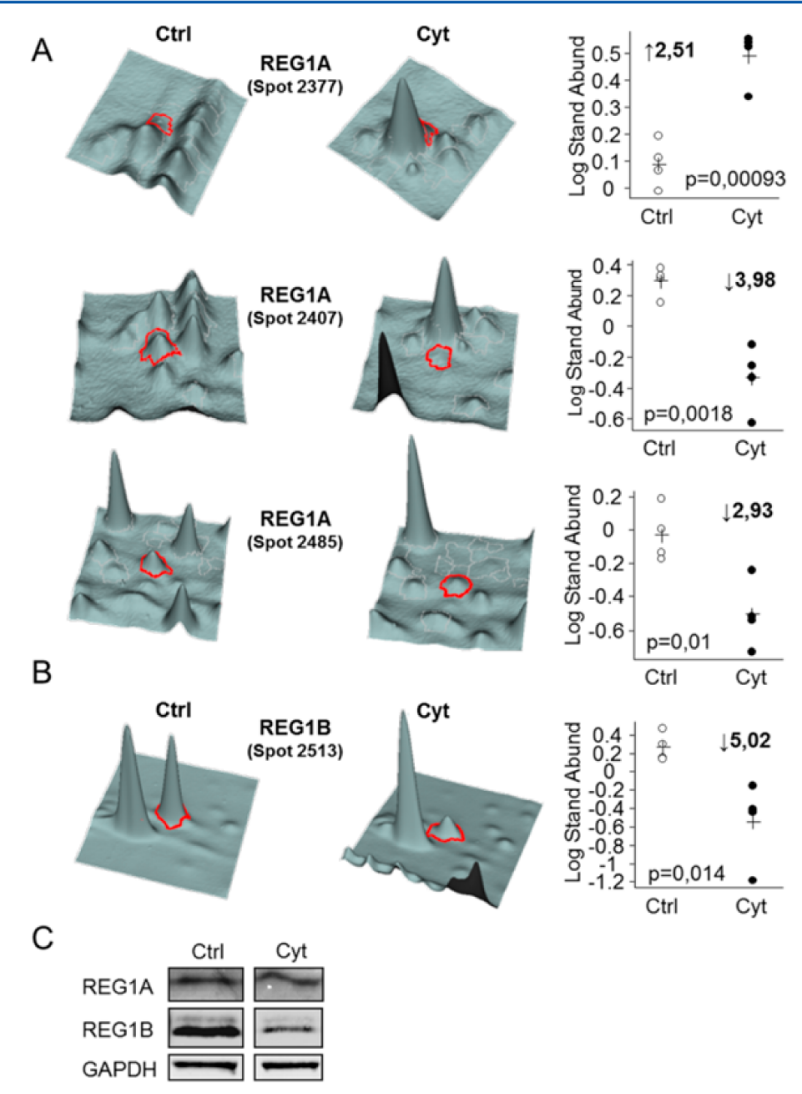

Figure 2. Regulation of REG1A and REG1B isoforms after cytokine treatment. (A) REG1A and (B) REG1B isoforms after IL- $1 \beta$ and IFN$\gamma$ treatment. Each isoform is illustrated by two representative $3 \mathrm{D}$ images, one of control (Ctrl) and one of cytokine-treated islets (Cyt) and the graph view of the DeCyder analysis $(n=4)$ for each particular spot with the standardized log abundance in the $y$ axis. (C) Total REG1A and REG1B protein levels of control or cytokine-treated islets. A representative image of a Western blot is shown $(n=3)$.

Suppl Figure 1 in the Supporting Information), these alterations are suggestive for post-translational modification of REG1A. As for REG1B, we observed decreased expression levels of the protein upon cytokine treatment (Figure 2B). Expression levels of both proteins were also analyzed on 1DE (Figure 2C), indicating no cytokine effect on total REG1A expression levels and a clear down-regulation of REG1B expression levels by cytokine treatment, further confirming the 2D-DIGE data.

\section{Cytokine Effect on tRNA Synthesis and Turnover}

In this functional group, aspartyl-tRNA synthetase was upregulated upon cytokine treatment of human islets. As for tryptophanyl-tRNA synthetase (TRPRS), one isoform (spot number 919) was found up-regulated, whereas another isoform (spot number 921) was found down-regulated. Further analysis of the position of both isoforms on the 2D-DIGE gels suggested the possible post-translational modification of cytoplasmic TRPRS upon cytokine treatment (Figure 3A). The expression

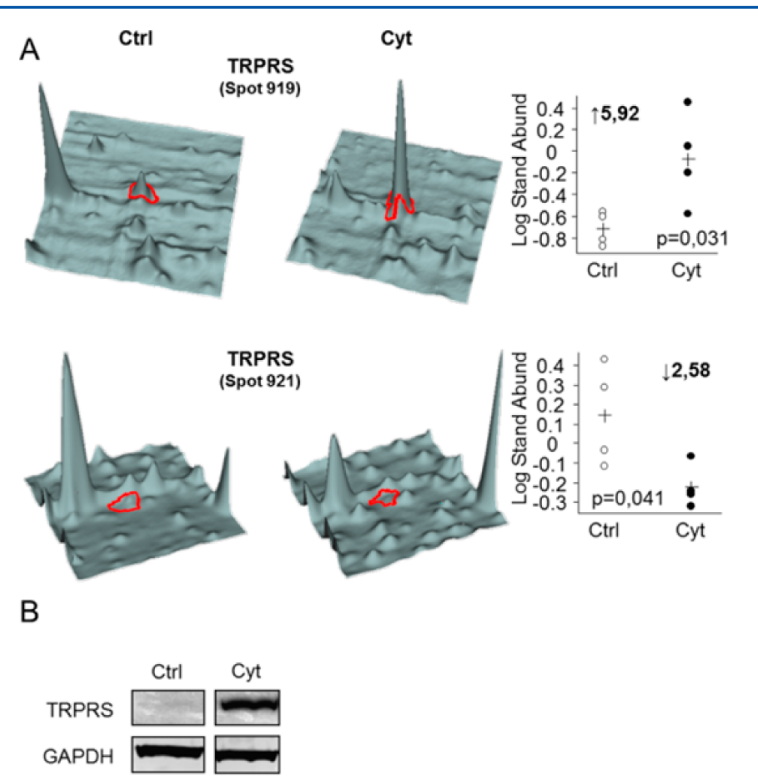

Figure 3. Regulation of TRPRS after cytokine treatment. (A) Each isoform is illustrated by two representative $3 \mathrm{D}$ images, one of control (Ctrl) and one of cytokine-treated islets (Cyt), and the graph view of the DeCyder analysis $(n=4)$ for each particular spot with the standardized log abundance in the $y$ axis. (B) Total TRPRS protein levels of control or cytokine-treated islets. A representative image of a Western blot is shown $(n=3)$.

level of the latter was also analyzed on 1DE (Figure 3B), indicating cytokine-induced expression levels of total TRPRS, most likely due to a proportional higher increase in the first isoform as compared with the induced decrease in the second isoform.

Protein Alterations Induced by GLP-1 in Control and Cytokine-Treated Human Islets

First of all, we investigated the effect of GLP-1 on the basal protein profile of human islets. Overall, only a minor effect on the protein profile was observed with a total of 10 identified protein expression alterations (Table 4 and Suppl. Figure 2 and Suppl. Table 2 in the Supporting Information).

Second, to identify players responsible for the beneficial effect of GLP-1 on cytokine-treated human islets, the proteomic profile of human islets exposed for $72 \mathrm{~h}$ to IL- $1 \beta / \mathrm{IFN}-\gamma$, combined with GLP-1, was determined. Compared with cytokinetreated islets, 16 spots were observed as differentially expressed by cotreatment with GLP-1 $(p<0.05)$ (Suppl. Figure 3 in the 
Table 4. Identification of Proteins with an Altered Expression Profile upon GLP-1 Treatment of Human Islets Compared to Controls

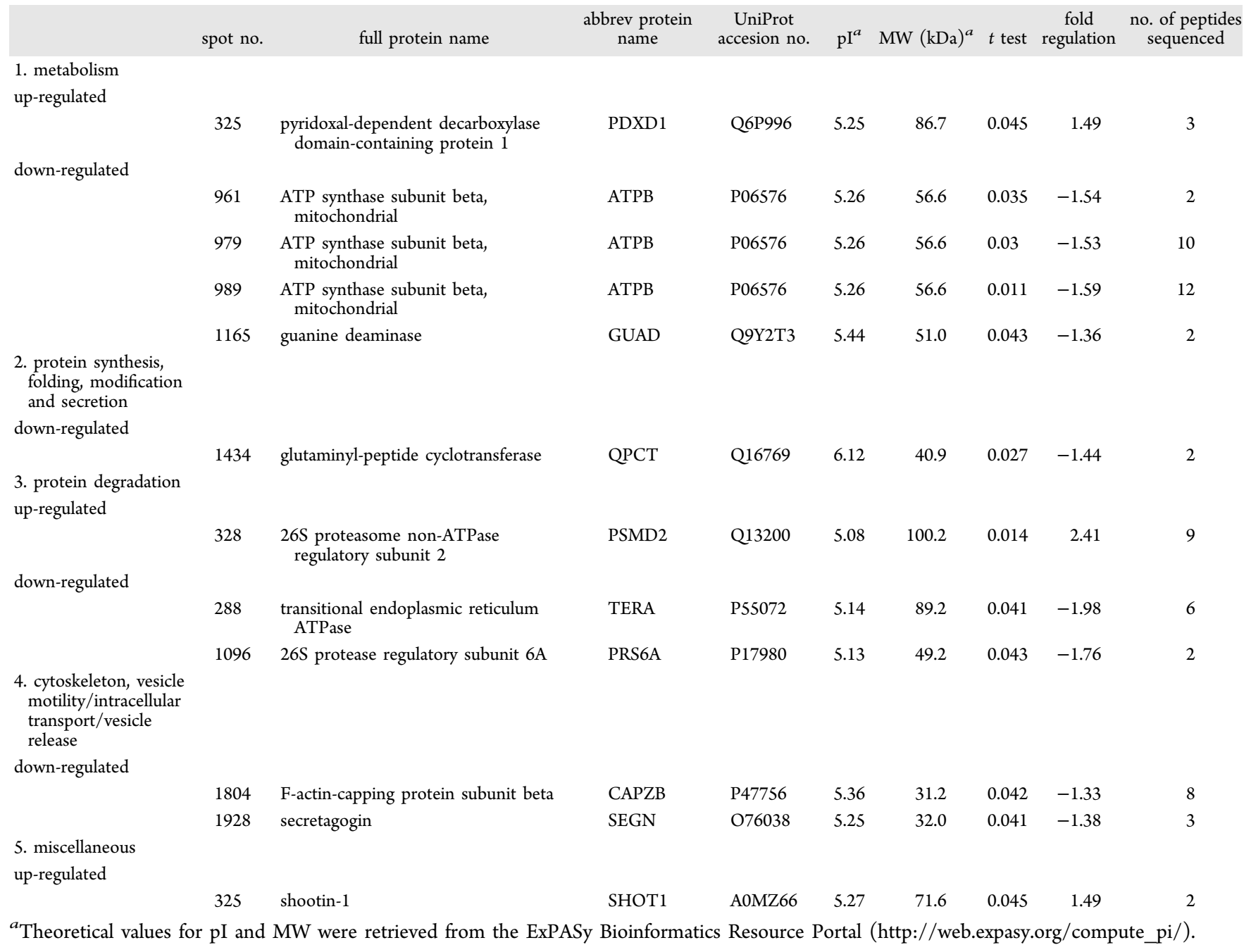

Supporting Information). Of these, 14 spots were unambiguously identified by MALDI-TOF/TOF, which corresponds to an overall identification rate of $87.5 \%$. Table 5 and Suppl. Table 3 in the Supporting Information show the complete list of identified proteins grouped in different functional classes.

Most interestingly, the majority of GLP-1-induced changes were observed in the functional class of the cytoskeleton and vesicle motility, which is in line with the protective effect of GLP-1 observed on apoptosis rate and GSIS. In this class, one of the two isoforms of ARP3, which is significantly decreased in cytokine-treated human islets (Table 3 ), is completely normalized upon coincubation with GLP-1 (Figure 4A). Furthermore, also two isoforms of the F-actin-capping protein subunit $\alpha 1$ were up-regulated upon GLP-1 treatment as compared with control cytokine-treated human islets. As for protein synthesis and processing, GLP-1 attenuated mitochondrial Stress-70 protein expression levels, whereas it augmented EIF3I expression in human islets treated with cytokines. In the functional class of defense and repair, two proteins, REG1A and UBE2N, are negatively regulated by GLP-1 as compared with the control cytokine-treated condition. As previously described, this REG1A isoform is found upregulated due to cytokine treatment as compared with control human islets (Figure 4B). Finally, we also observed a GLP-1-induced up-regulation of the metabolic protein pyruvate dehydrogenase beta that acts as an essential link between glycolysis and Krebs cycle.

\section{Network Analysis}

To investigate whether the identified, differentially expressed proteins work together in specific networks, we analyzed the potential interactions between these proteins making use of a sophisticated network program recently developed ${ }^{32}$ (Figure 5). This allowed us to examine whether the differentially expressed proteins from one or more functional pathways interact with each other and to place them in a framework of cellular systems. Note that to construct these networks we also considered first-order interaction partners (gray circles) of the identified proteins because these linker proteins enable us to get a more complete view on the proteins and pathways affected by each treatment.

The network generated for cytokine-treated human islets includes 30 out of 58 distinct proteins identified $\left(p<1.0 \times 10^{-4}\right)$. As shown in Figure 5B, this complex network contains proteins from different functional classes, suggesting extensive cross-talk between the proteins and pathways in which they are involved. This indicates that cytokine treatment of human islets results in a complex interaction between proteins from different functional classes, finally resulting in the observed cytokine-induced effects on $\beta$-cell function and destruction. Central in this 
Table 5. Identification of Proteins with an Altered Expression Profile upon IL-1 $\beta$, IFN- $\gamma$, and GLP-1 Treatment of Human Islets Compared to IL-1 $\beta$ and IFN- $\gamma$ Treatment

\begin{tabular}{|c|c|c|c|c|c|c|c|c|c|}
\hline & spot no. & full protein name & $\begin{array}{l}\text { abbrev protein } \\
\text { name }\end{array}$ & $\begin{array}{l}\text { UniProt } \\
\text { accesion no. }\end{array}$ & $\mathrm{pI}^{a}$ & $\mathrm{MW}(\mathrm{kDa})^{a}$ & $t$ test & $\begin{array}{l}\text { fold } \\
\text { regulation }\end{array}$ & $\begin{array}{l}\text { no. of peptides } \\
\text { sequenced }\end{array}$ \\
\hline \multicolumn{10}{|l|}{ 1. metabolism } \\
\hline \\
\hline & 958 & $\begin{array}{l}\text { aldehyde dehydrogenase, mitochondri- } \\
\text { al }\end{array}$ & ALDH2 & P05091 & 6.63 & 56.4 & 0.04 & 1.38 & 2 \\
\hline & 1563 & $\begin{array}{l}\text { pyruvate dehydrogenase E1 compo- } \\
\text { nent subunit beta, mitochondrial }\end{array}$ & ODBP & P11177 & 6.20 & 39.2 & 0.01 & 1.99 & 4 \\
\hline \multicolumn{10}{|c|}{$\begin{array}{l}\text { 2.proteinsynthesis,fold- } \\
\text { ing, modifica- } \\
\text { tion and secretion }\end{array}$} \\
\hline \multicolumn{10}{|l|}{ up-regulated } \\
\hline & 1501 & $\begin{array}{l}\text { eukaryotic translation initiation fac- } \\
\text { tor } 3 \text { subunit I }\end{array}$ & EIF3I & Q13347 & 5.38 & 36.5 & 0.04 & 1.75 & 3 \\
\hline \multicolumn{10}{|l|}{ down-regulated } \\
\hline & 501 & stress- 70 protein, mitochondrial & GRP75 & P38646 & 5.87 & 73.7 & 0.02 & -1.5 & 4 \\
\hline \multirow{2}{*}{\multicolumn{10}{|c|}{$\begin{array}{l}\text { 3. signal transduction } \\
\text { down-regulated }\end{array}$}} \\
\hline & & & & & & & & & \\
\hline & 1704 & annexin A3 & ANXA3 & P12429 & 5.63 & 36.2 & 0.03 & -2.08 & 4 \\
\hline \multicolumn{10}{|c|}{$\begin{array}{l}\text { 4. cytoskeleton, vesi- } \\
\text { cle motility/intracel- } \\
\text { lular transport/vesi- } \\
\text { cle release }\end{array}$} \\
\hline \multicolumn{10}{|l|}{ up-regulated } \\
\hline & 1063 & actin-related protein 3 & ARP3 & P61158 & 5.61 & 47.2 & 0.05 & 1.73 & 4 \\
\hline & 1373 & actin, cytoplasmic 1 & ACTB & P60709 & 5.29 & 41.7 & 0.02 & 2.69 & 3 \\
\hline & 1557 & $\begin{array}{l}\text { F-actin-capping protein subunit al- } \\
\text { pha-1 }\end{array}$ & CAZA1 & P52907 & 5.45 & 32.8 & 0.05 & 1.61 & 6 \\
\hline & 1563 & $\begin{array}{l}\text { F-actin-capping protein subunit al- } \\
\text { pha-1 }\end{array}$ & CAZA1 & P52907 & 5.45 & 32.8 & 0.01 & 1.99 & 5 \\
\hline \multicolumn{10}{|l|}{ down-regulated } \\
\hline & 1704 & annexin A4 & ANXA4 & P09525 & 5.84 & 35.8 & 0.03 & -2.08 & 5 \\
\hline \multicolumn{10}{|c|}{$\begin{array}{l}\text { 5. RNA synthesis/turn- } \\
\text { over }\end{array}$} \\
\hline \multicolumn{10}{|l|}{ up-regulated } \\
\hline & 958 & $\begin{array}{l}\text { heterogeneous nuclear ribonucleopro- } \\
\text { tein } \mathrm{H}\end{array}$ & HNRH1 & P31943 & 5.89 & 49.2 & 0.04 & 1.38 & 2 \\
\hline \multirow{2}{*}{\multicolumn{10}{|c|}{$\begin{array}{l}\text { 6. defense and repair } \\
\text { down-regulated }\end{array}$}} \\
\hline & & & & & & & & & \\
\hline & 2377 & $\begin{array}{l}\text { lithostathine-1-alpha // Islet of Langer- } \\
\text { hans regenerating protein }\end{array}$ & REG1A & P05451 & 5.65 & 18.7 & 0.01 & -1.85 & 7 \\
\hline & 2463 & ubiquitin-conjugating enzyme E2 N & UBE2N & P61088 & 6.13 & 17.1 & 0.02 & -1.51 & 2 \\
\hline \multirow{2}{*}{\multicolumn{10}{|c|}{$\begin{array}{l}\text { 7. miscellaneous } \\
\text { down-regulated }\end{array}$}} \\
\hline & & & & & & & & & \\
\hline & 625 & guanylate-binding protein 5 & GBP5 & Q96PP8 & 5.38 & 66.3 & 0.05 & -1.35 & 5 \\
\hline
\end{tabular}

network are the proteins involved in the organization of the cytoskeleton and vesicle motility (green circles). As shown in Figure 5C, the network generated for cytokine- and GLP-1treated human islets (as compared with cytokine-treated islets) includes 8 out of 13 differentially expressed proteins $\left(p<1.0 \times 10^{-6}\right)$ with again a central role for 4 proteins involved in cytoskeleton organization and vesicle motility (green circles). Thus, these networks suggest an important role for structural proteins such as ACTB, ARP3, and CAZA1 in both cytokine-induced $\beta$-cell dysfunction and destruction and the protective effect of GLP-1 on cytokinetreated $\beta$-cells.

\section{DISCUSSION}

In this study, we investigated the protective effects of GLP-1 on human islets of Langerhans in a setting relevant for both type-1 and type- 2 diabetes, namely, in vitro exposure of whole human islets to the pro-inflammatory cytokines IL- $1 \beta$ and IFN- $\gamma$. To investigate the underlying molecular pathways associated with the observed effects of GLP-1 on $\beta$-cell dysfunction and destruction, we performed a full proteome and protein interaction network analysis. Because $72 \mathrm{~h}$ of cytokine treatment resulted in only $18 \pm 3.5 \%$ apoptotic $\beta$-cells, we decided to maintain these culture conditions for proteomic analysis, which thereby allowed us to identify networks of 
proteins directly associated with the observed cytotoxic effect of cytokines and most importantly the cytoprotective action of GLP-1. Indeed, human islets are somewhat less susceptible to treatment with the combination of IL- $1 \beta$ and IFN- $\gamma$, as compared with INS-1E cells, where a similar percentage of apoptotic cells is already reached after $24 \mathrm{~h}$ of treatment. ${ }^{17}$ The use of
A

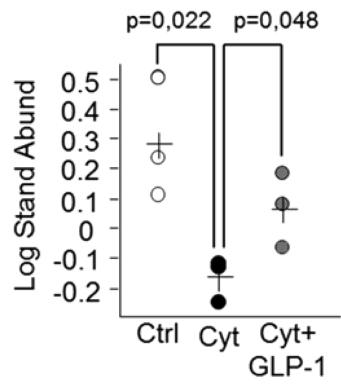

B

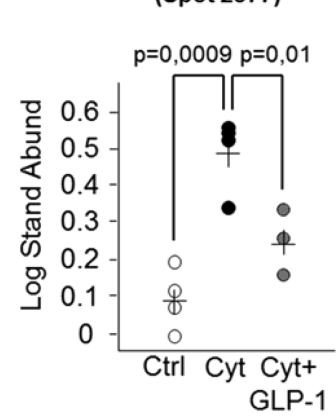

Figure 4. Regulation of ARP3 and REG1A after cytokine treatment with or without GLP-1. (A) ARP3 (spot 1063) and (B) REG1A (spot 2377). The respective intensities of the different CyDye-labeled isoforms of control (Ctrl), cytokine-treated (Cyt), and cytokine + GLP-1-treated (Cyt + GLP-1) human islets were quantified and expressed as standardized log abundance in the graph view $(n=4)$. whole human islets enabled us to confirm different important pathways that are involved in cytokine-mediated $\beta$-cell destruction, extending our previous findings in rodent-derived INS-1E cells toward a more physiological model. ${ }^{17}$ GLP-1 by itself affected the proteome profile of human islets only in a minor way, with only 10 proteins altered versus unexposed islets. However, when human islets were treated with the cytokine mixture IL- $1 \beta$ and IFN- $\gamma$, inducing increased apoptosis and decreased GSIS, a clear cytoprotective effect of GLP-1 was observed upon coincubation, correlating with published in vitro studies in human islets ${ }^{14}$ and in vivo studies in murine models. ${ }^{33-35}$ Of note, despite the restoring effect of GLP-1 on cytokinemediated inhibition of GSIS, GLP-1 did not alter the cytokinemediated decrease in insulin granule density. A possible explanation for this apparent contradiction might be that GLP-1 positively affects the exocytotic machinery (reviewed in ref 36) but has no effect on cytokine-mediated decrease in insulin production and thereby insulin granule density.

To analyze the proteome of cytokine- and GLP-1-treated human islets, we used high-resolution 2D-DIGE. Although more labor-intensive and somewhat less sensitive compared with gel-free proteomic techniques such as iTRAQ this technique has the advantage to provide information on the mass and isoelectric point of the detected proteins, enabling us to detect post-translational modifications of specific proteins. The latter, in particular, may play an important role in the
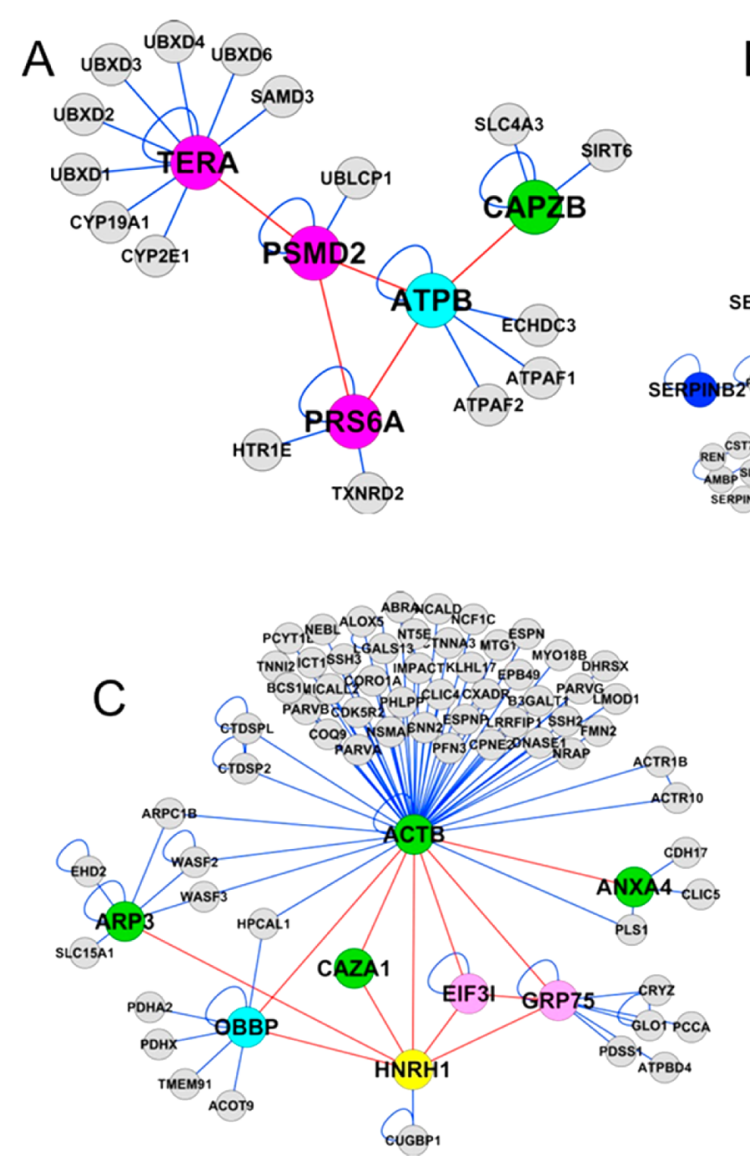

B cxaor

B

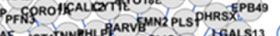

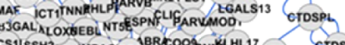

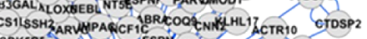

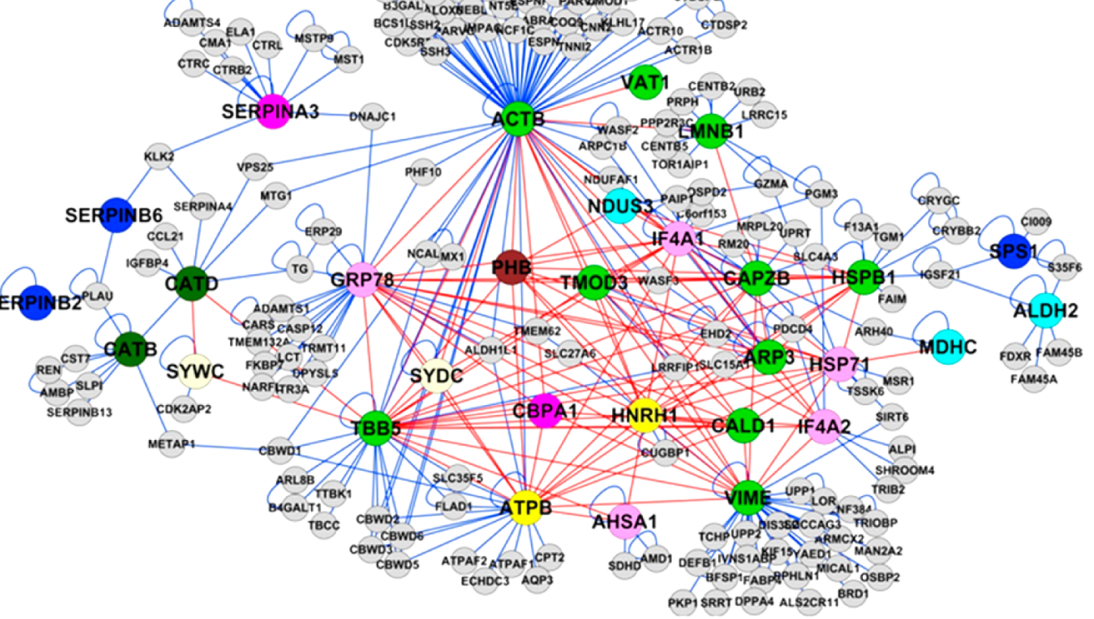

Metabolism

Protein synthesis, folding, modification, secretion

Protein degradation

Cytoskeleton, vesicle motility/intracellular transport/vesicle release

RNA synthesis/turnover

tRNA synthesis/turnover

Cell cycle and related genes

Apoptosis

Miscellaneous

Figure 5. Network analysis of the identified differential expressed proteins after cytokine or GLP-1 treatment. (A) Treatment with $10 \mathrm{nM}$ GLP-1 $\left(p<0.001\right.$ compared with control islets). (B) Treatment with IL- $1 \beta$ and IFN- $\gamma\left(p<1.0 \times 10^{-4}\right.$ compared with control islets) and (C) treatment with IL-1 $\beta$, IFN- $\gamma$, and GLP-1 $\left(p<1.0 \times 10^{-6}\right.$ compared with IL-1 $\beta$ - and IFN- $\gamma$-treated islets). Colored circles represent proteins that were identified in this study and gray circles represent interconnecting proteins revealed by the network software program. The identified proteins were colored according to their function as indicated in the Figure. 
loss of immune tolerance during the development of type-1 diabetes. $^{37}$

Analysis of the mass spectrometry data revealed that the majority of the identified proteins are, consistent with previous studies performed on rat islets, ${ }^{38,39}$ involved in protein synthesis and degradation, cytoskeleton (re)organization, and metabolism. One of the characteristic features of $\beta$-cells is a highly developed ER to fold, process, and export newly synthesized insulin. ${ }^{40}$ It is thereby also believed that $\beta$-cells represent one of the most susceptible cell types for ER stress. Moreover, a recent publication from Fonseca and colleagues ${ }^{41}$ illustrates an important role for the ER protein Wolfram syndrome 1 (WFS1) as a regulator of both the ER stress signaling pathway and glucoseand GLP-1-induced insulin secretion. Central in the cellular protection mechanism against ER stress, called the unfolded protein response (UPR), are the ER chaperones, which are involved in protein folding and prevention of aggregation of unfolded or misfolded proteins. In line with our previously published data on INS-1E cells ${ }^{17}$ and the previous report on IL- $1 \beta$-treated rat islets, ${ }^{39}$ we observed several ER chaperones that were down-regulated upon cytokine treatment of human islets, which may partially explain the cytotoxic effect of cytokines on $\beta$-cells. More specifically, EIF4A isoforms 2 and 1 were identified as being down-regulated upon cytokine exposure of human islets. This cytokine-mediated decrease in EIF4A expression levels can inhibit cap-dependent insulin biosynthesis in $\beta$-cells. ${ }^{42}$ GLP-1 had pronounced counteractive effects on the cytokine-induced alterations of these ER stressrelated proteins. As such, the observed GLP-1-mediated upregulation of EIF3I, a translation initiation factor that is shown to play a prominent role in fibroblast proliferation, ${ }^{43}$ might attenuate the cytokine-mediated decrease in EIF4A expression. In addition, on the basis of the reported functional role of GRP75 in cytokinemediated $\beta$-cell destruction, indicating a positive correlation between GRP75 expression levels in rat islets and cytokine susceptibility, ${ }^{44}$ also the GLP-1-mediated down-regulation of GRP75 is consistent with the protective effect of GLP-1 against cytokine-induced $\beta$-cell death. However, in contrast with Johannesen and colleagues, ${ }^{44}$ we were not able to identify a significant increase in GRP75 expression following cytokine treatment, which might be due to differences in experimental setup such as the usage of human islets, as opposed to rodent islets, treatment with different cytokines, and different incubation times.

Another functional class strongly affected by cytokine as well as GLP-1 exposure of human islets was the class of proteins involved in cytoskeleton organization and vesicle motility. It is well-established that the actin cytoskeleton and its remodeling are crucial to GSIS. Moreover, this remodeling process has been shown to be indispensable for insulin granules to get in close proximity with their docking sites as well as for activating specific compounds of the exocytotic machinery such as the t-SNARE complex, thereby facilitating docking and fusion of the insulin secretory granules with the plasma membrane and secretion of their content. ${ }^{45,46}$ In addition, we already observed and described the effect of a $24 \mathrm{~h}$ cytokine treatment on the reorganization of filamentous actin (F-actin) in rodent INS-1E cells. ${ }^{17}$ The dynamic assembly and disassembly of filaments and the formation of larger scale filament structures, F-actin out of monomeric G-actin, are crucial aspects of the function of actin and are therefore under scrupulous control by over 100 actinbinding proteins. $^{47}$ In this study, we identified multiple cytokine- and GLP-1-responsive proteins such as actin-related protein 3 (ARP3), F-actin-capping protein subunit beta (CAPZB), and heat shock protein beta-1 (HSPB1), which are involved in F-actin polymerization ${ }^{48,49}$ as well as proteins such as tropomodulin-3 (TMOD3), which is involved in actin depolymerization. ${ }^{50}$ Cytokine-mediated down-regulation of these proteins in human $\beta$-cells most likely disrupts the dynamic equilibrium between monomeric G-actin and filamentous F-actin and in this way inhibits GSIS. Interestingly, these changes were found to be counteracted by GLP-1 through an up-regulation of ARP3 and the F-actin-capping protein subunit $\alpha 1$. This GLP-1 effect might hence, at least partially, restore the disrupted equilibrium, thereby normalizing the cytokine-mediated inhibition of GSIS.

Similar to Tews and colleagues, ${ }^{18}$ we also observed a cytokinemediated down-regulation of proteins involved in the electrontransport chain, which can be linked to oxidative stress and eventually to apoptosis. In contrast with this previous study, we did not observe a normalizing effect of GLP-1 on the expression levels of these proteins. This apparent discrepancy might be explained by the different setups used in both approaches (e.g., INS-1E cell line vs human islets and analysis of mitochondrial fraction vs full lysates). We observed a GLP-1-induced normalization of the cytokine-mediated decrease in mitochondrial aldehyde dehydrogenase, which possibly functions as a protection against the cytokine-induced production of cytotoxic aldehydes. ${ }^{51}$ Furthermore, cytokine treatment of human islets also resulted in the down-regulation of mitochondrial SuccinylCoA ligase [GDP-forming] subunit beta, which is known to have a negative impact on the Krebs cycle and GSIS. ${ }^{52}$ This might be counteracted by the GLP-1-induced expression and activation of the mitochondrial pyruvate dehydrogenase E1 component subunit beta, which functions, in its complex, as the primary link between glycolysis and the Krebs cycle and thereby positively affects GSIS. ${ }^{53}$ These data correspond with the findings of Sparre and colleagues, ${ }^{39}$ who showed a reduced energy production in rat islets upon IL- $1 \beta$ exposure. Furthermore, we also observed a clear effect on REG1A and REG1B, which are acinar cell-derived proliferation factors shown to be involved in $\beta$-cell proliferation. ${ }^{54}$ Several members of the Reg gene family have already been identified as being induced by GLP-1, ${ }^{55}$ although this is the first report in human islets. However, overexpression of REG1 has also been associated with accelerated diabetes in NOD mice ${ }^{56}$ and has been shown to inhibit $\beta$-cell growth and possibly induces apoptosis. ${ }^{54}$ This dual action is probably reflected in the observed differential effect of cytokines on the expression profiles of REG1A and REG1B. Indeed, we observed an opposite regulation of different PTM-isoforms of the Reg family members. Interestingly, GLP-1-mediated down-regulation of the cytokine-induced REG1A isoform might be able to normalize the detrimental effect of this increase in REG1A expression. Although the exact nature and role of the observed PTMs need further investigation, this finding points to an important role of PTMs in the protective effect of GLP-1.

In summary, we confirm the protective effect of GLP-1 against cytokine-induced $\beta$-cell dysfunction and destruction in human islets of Langerhans. In addition, this study provides the first protein expression profile of GLP-1-exposed human $\beta$-cells in their physiological environment, namely, intact human islets. These data support the diversity and complexity of the underlying, both protective and deleterious, mechanisms implicated in cytokine-mediated $\beta$-cell dysfunction and destruction underlining the importance of proteins of different 
functional classes, such as chaperones, cytoskeleton reorganization, metabolism, and islet regenerating proteins. In addition, the analysis of quantitative changes in protein expression levels and elucidation of protein interaction networks revealed that the cytoprotective effects of GLP-1 are mainly executed through counteracting the effects of cytokines on these same pathways/proteins. These observations may be important in the context of type- 1 diabetes, where immune cells and immune cytokines have been described to contribute to $\beta$-cell dysfunction. Clinical trials evaluating a putative beneficial effect of the GLP-1 receptor agonists and even the DPP4 inhibitors on $\beta$-cell function and mass are under way. Also, in type- 2 diabetes, an important role for inflammation in the progressive failure of the $\beta$-cell function and even mass has been proposed. Thus, our data may add to a better case for exploiting the incretin system in both type- 1 and type- 2 diabetes as agents that may be improving $\beta$-cell health.

\section{ASSOCIATED CONTENT}

\section{S Supporting Information}

Additional mass spectrometric information of the individual peptide sequences and annotated 2D-gel images. This material is available free of charge via the Internet at http://pubs.acs.org.

\section{AUTHOR INFORMATION}

\section{Corresponding Author}

*Tel: +32 16 346163. Fax: +32 16 346035. E-mail: lut. overbergh@med.kuleuven.be.

\section{Author Contributions}

$\nabla_{\text {C.M. and L.O. contributed equally. }}$

Notes

The authors declare no competing financial interest.

\section{ACKNOWLEDGMENTS}

The technical experience of Eefje Verdrengh and Sandy Vandoninck is greatly appreciated. This work was supported by the European Community's seventh Framework Programme NAIMIT under grant agreement no. 241447, the KU Leuven (Geconcerteerde Onderzoeksactie 2009/10 and GOA 12/24), the Flemish Research Foundation (FWO G.0649.08, G.0619.12 and a clinical research fellowship for C.M.) and the Juvenile Diabetes Research Foundation International (17-2012-129), and a grant of the Interuniversity Attraction Poles Program (P7/13)-Belgian Federal Science Policy.

\section{ABBREVIATIONS:}

2D-DIGE, two-dimensional difference gel electrophoresis; GLP-1, glucagon-like peptide-1; GSIS, glucose-stimulated insulin secretion

\section{REFERENCES}

(1) Donath, M. Y.; Boni-Schnetzler, M.; Ellingsgaard, H.; Halban, P. A.; Ehses, J. A. Cytokine production by islets in health and diabetes: cellular origin, regulation and function. Trends Endocrinol. Metab. 2010, 21 (5), 261-267.

(2) Wang, C.; Guan, Y.; Yang, J. Cytokines in the progression of pancreatic beta-cell dysfunction. Int J Endocrinol 2010, 2010, 515136.

(3) Alexandraki, K.; Piperi, C.; Kalofoutis, C.; Singh, J.; Alaveras, A.; Kalofoutis, A. Inflammatory process in type 2 diabetes: The role of cytokines. Ann. N.Y. Acad. Sci. 2006, 1084, 89-117.

(4) Eizirik, D. L.; Sammeth, M.; Bouckenooghe, T.; Bottu, G.; Sisino, G.; Igoillo-Esteve, M.; Ortis, F.; Santin, I.; Colli, M. L.; Barthson, J.;
Bouwens, L.; Hughes, L.; Gregory, L.; Lunter, G.; Marselli, L.; Marchetti, P.; McCarthy, M. I.; Cnop, M. The human pancreatic islet transcriptome: expression of candidate genes for type 1 diabetes and the impact of pro-inflammatory cytokines. PLoS Genet. 2012, 8 (3), e1002552.

(5) Gysemans, C. A.; Ladriere, L.; Callewaert, H.; Rasschaert, J.; Flamez, D.; Levy, D. E.; Matthys, P.; Eizirik, D. L.; Mathieu, C. Disruption of the gamma-interferon signaling pathway at the level of signal transducer and activator of transcription-1 prevents immune destruction of beta-cells. Diabetes 2005, 54 (8), 2396403.

(6) Cnop, M.; Welsh, N.; Jonas, J. C.; Jorns, A.; Lenzen, S.; Eizirik, D. L. Mechanisms of pancreatic beta-cell death in type 1 and type 2 diabetes: many differences, few similarities. Diabetes 2005, 54 (Suppl 2), S97-S107.

(7) Cardozo, A. K.; Ortis, F.; Storling, J.; Feng, Y. M.; Rasschaert, J.; Tonnesen, M.; Van Eylen, F.; Mandrup-Poulsen, T.; Herchuelz, A.; Eizirik, D. L. Cytokines downregulate the sarcoendoplasmic reticulum pump $\mathrm{Ca} 2+$ ATPase $2 \mathrm{~b}$ and deplete endoplasmic reticulum $\mathrm{Ca} 2+$, leading to induction of endoplasmic reticulum stress in pancreatic beta-cells. Diabetes 2005, 54 (2), 452-461.

(8) Marchetti, P.; Lupi, R.; Bugliani, M.; Kirkpatrick, C. L.; Sebastiani, G.; Grieco, F. A.; Del Guerra, S.; D’Aleo, V.; Piro, S.; Marselli, L.; Boggi, U.; Filipponi, F.; Tinti, L.; Salvini, L.; Wollheim, C. B.; Purrello, F.; Dotta, F. A local glucagon-like peptide 1 (GLP-1) system in human pancreatic islets. Diabetologia 2012, 55 (12), 32623272.

(9) Drucker, D. J. The biology of incretin hormones. Cell Metab. 2006, 3 (3), 153-165.

(10) Baggio, L. L.; Drucker, D. J. Biology of incretins: GLP-1 and GIP. Gastroenterology 2007, 132 (6), 2131-2157.

(11) Bulotta, A.; Farilla, L.; Hui, H.; Perfetti, R. The role of GLP-1 in the regulation of islet cell mass. Cell Biochem. Biophys. 2004, 40 (3 Suppl), 65-78.

(12) Hui, H.; Nourparvar, A.; Zhao, X.; Perfetti, R. Glucagon-like peptide-1 inhibits apoptosis of insulin-secreting cells via a cyclic $5^{\prime}$ adenosine monophosphate-dependent protein kinase $\mathrm{A}$ - and a phosphatidylinositol 3-kinase-dependent pathway. Endocrinology 2003, 144 (4), 1444-1455.

(13) Sarkar, S. A.; Gunter, J.; Bouchard, R.; Reusch, J. E.; Wiseman, A.; Gill, R. G.; Hutton, J. C.; Pugazhenthi, S. Dominant negative mutant forms of the cAMP response element binding protein induce apoptosis and decrease the anti-apoptotic action of growth factors in human islets. Diabetologia 2007, 50 (8), 1649-1659.

(14) Velmurugan, K.; Balamurugan, A. N.; Loganathan, G.; Ahmad, A.; Hering, B. J.; Pugazhenthi, S. Antiapoptotic actions of exendin-4 against hypoxia and cytokines are augmented by CREB. Endocrinology 2012, 153 (3), 1116-1128.

(15) Holst, J. J.; Christensen, M.; Lund, A.; de Heer, J.; Svendsen, B.; Kielgast, U.; Knop, F. K. Regulation of glucagon secretion by incretins. Diabetes, Obes. Metab. 2011, 13 (Suppl 1), 89-94.

(16) Suen, C. S.; Burn, P. The potential of incretin-based therapies in type 1 diabetes. Drug Discovery Today 2012, 17 (1-2), 89-95.

(17) D’Hertog, W.; Overbergh, L.; Lage, K.; Ferreira, G. B.; Maris, M.; Gysemans, C.; Flamez, D.; Cardozo, A. K.; Van den Bergh, G.; Schoofs, L.; Arckens, L.; Moreau, Y.; Hansen, D. A.; Eizirik, D. L.; Waelkens, E.; Mathieu, C. Proteomics analysis of cytokine-induced dysfunction and death in insulin-producing INS-1E cells: new insights into the pathways involved. Mol. Cell. Proteomics 2007, 6 (12), 2180 2199.

(18) Tews, D.; Lehr, S.; Hartwig, S.; Osmers, A.; Paslack, W.; Eckel, J. Anti-apoptotic action of exendin-4 in INS-1 beta cells: comparative protein pattern analysis of isolated mitochondria. Horm. Metab. Res. 2009, 41 (4), 294-301.

(19) Rieneck, K.; Bovin, L. F.; Josefsen, K.; Buschard, K.; Svenson, M.; Bendtzen, K. Massive parallel gene expression profiling of RINm5F pancreatic islet beta-cells stimulated with interleukin-1beta. APMIS 2000, 108 (12), 855-872. 
(20) Cardozo, A. K.; Kruhoffer, M.; Leeman, R.; Orntoft, T.; Eizirik, D. L. Identification of novel cytokine-induced genes in pancreatic betacells by high-density oligonucleotide arrays. Diabetes 2001, 50 (5), 909-920.

(21) Rasschaert, J.; Liu, D.; Kutlu, B.; Cardozo, A. K.; Kruhoffer, M.; TF, O. R.; Eizirik, D. L. Global profiling of double stranded RNA- and IFN-gamma-induced genes in rat pancreatic beta cells. Diabetologia 2003, 46 (12), 1641-1657.

(22) Kutlu, B.; Cardozo, A. K.; Darville, M. I.; Kruhoffer, M.; Magnusson, N.; Orntoft, T.; Eizirik, D. L. Discovery of gene networks regulating cytokine-induced dysfunction and apoptosis in insulinproducing INS-1 cells. Diabetes 2003, 52 (11), 2701-2719.

(23) Kutlu, B.; Burdick, D.; Baxter, D.; Rasschaert, J.; Flamez, D.; Eizirik, D. L.; Welsh, N.; Goodman, N.; Hood, L. Detailed transcriptome atlas of the pancreatic beta cell. BMC Med. Genomics 2009, 2, 3.

(24) Sarkar, S. A.; Kutlu, B.; Velmurugan, K.; Kizaka-Kondoh, S.; Lee, C. E.; Wong, R.; Valentine, A.; Davidson, H. W.; Hutton, J. C.; Pugazhenthi, S. Cytokine-mediated induction of anti-apoptotic genes that are linked to nuclear factor kappa-B (NF-kappaB) signalling in human islets and in a mouse beta cell line. Diabetologia 2009, 52 (6), $1092-1101$.

(25) Gurzov, E. N.; Barthson, J.; Marhfour, I.; Ortis, F.; Naamane, N.; Igoillo-Esteve, M.; Gysemans, C.; Mathieu, C.; Kitajima, S.; Marchetti, P.; Orntoft, T. F.; Bakiri, L.; Wagner, E. F.; Eizirik, D. L. Pancreatic beta-cells activate a JunB/ATF3-dependent survival pathway during inflammation. Oncogene 2012, 31 (13), 1723-1732.

(26) Mann, M.; Jensen, O. N. Proteomic analysis of post-translational modifications. Nat. Biotechnol. 2003, 21 (3), 255-261.

(27) Bugliani, M.; Masini, M.; Liechti, R.; Marselli, L.; Xenarios, I.; Boggi, U.; Filipponi, F.; Masiello, P.; Marchetti, P. The direct effects of tacrolimus and cyclosporin A on isolated human islets: A functional, survival and gene expression study. Islets 2009, 1 (2), 106-110.

(28) Marchetti, P.; Bugliani, M.; Lupi, R.; Marselli, L.; Masini, M.; Boggi, U.; Filipponi, F.; Weir, G. C.; Eizirik, D. L.; Cnop, M. The endoplasmic reticulum in pancreatic beta cells of type 2 diabetes patients. Diabetologia 2007, 50 (12), 2486-2494.

(29) Masini, M.; Bugliani, M.; Lupi, R.; del Guerra, S.; Boggi, U.; Filipponi, F.; Marselli, L.; Masiello, P.; Marchetti, P. Autophagy in human type 2 diabetes pancreatic beta cells. Diabetologia 2009, 52 (6), $1083-1086$.

(30) Dotta, F.; Censini, S.; van Halteren, A. G.; Marselli, L.; Masini, M.; Dionisi, S.; Mosca, F.; Boggi, U.; Muda, A. O.; Prato, S. D.; Elliott, J. F.; Covacci, A.; Rappuoli, R.; Roep, B. O.; Marchetti, P. Coxsackie B4 virus infection of beta cells and natural killer cell insulitis in recentonset type 1 diabetic patients. Proc. Natl. Acad. Sci. U. S. A. 2007, 104 (12), 5115-5120.

(31) Watanabe, T.; Yonemura, Y.; Yonekura, H.; Suzuki, Y.; Miyashita, H.; Sugiyama, K.; Moriizumi, S.; Unno, M.; Tanaka, O.; Kondo, H.; et al. Pancreatic beta-cell replication and amelioration of surgical diabetes by Reg protein. Proc. Natl. Acad. Sci. U. S. A. 1994, 91 (9), 3589-3592.

(32) Lage, K.; Karlberg, E. O.; Storling, Z. M.; Olason, P. I.; Pedersen, A. G.; Rigina, O.; Hinsby, A. M.; Tumer, Z.; Pociot, F.; Tommerup, N.; Moreau, Y.; Brunak, S. A human phenomeinteractome network of protein complexes implicated in genetic disorders. Nat. Biotechnol. 2007, 25 (3), 309-316.

(33) Tourrel, C.; Bailbe, D.; Lacorne, M.; Meile, M. J.; Kergoat, M.; Portha, B. Persistent improvement of type 2 diabetes in the GotoKakizaki rat model by expansion of the beta-cell mass during the prediabetic period with glucagon-like peptide-1 or exendin-4. Diabetes 2002, 51 (5), 1443-1452.

(34) Rolin, B.; Larsen, M. O.; Gotfredsen, C. F.; Deacon, C. F.; Carr, R. D.; Wilken, M.; Knudsen, L. B. The long-acting GLP-1 derivative NN2211 ameliorates glycemia and increases beta-cell mass in diabetic mice. Am. J. Physiol.: Endocrinol. Metab. 2002, 283 (4), E745-E752.

(35) Doyle, M. E.; Egan, J. M. Mechanisms of action of glucagon-like peptide 1 in the pancreas. Pharmacol. Ther. 2007, 113 (3), 546-593.
(36) Meloni, A. R.; Deyoung, M. B.; Lowe, C.; Parkes, D. G. GLP-1 receptor activated insulin secretion from pancreatic beta-cells: mechanism and glucose dependence. Diabetes, Obes. Metab. 2013, 15 (1), 15-27.

(37) Dunne, J. L.; Overbergh, L.; Purcell, A. W.; Mathieu, C. Posttranslational modifications of proteins in type 1 diabetes: the next step in finding the cure? Diabetes 2012, 61 (8), 1907-1914.

(38) Larsen, P. M.; Fey, S. J.; Larsen, M. R.; Nawrocki, A.; Andersen, H. U.; Kahler, H.; Heilmann, C.; Voss, M. C.; Roepstorff, P.; Pociot, F.; Karlsen, A. E.; Nerup, J. Proteome analysis of interleukin-1betainduced changes in protein expression in rat islets of Langerhans. Diabetes 2001, 50 (5), 1056-1063.

(39) Sparre, T.; Christensen, U. B.; Mose Larsen, P.; Fey, S. J.; Wrzesinski, K.; Roepstorff, P.; Mandrup-Poulsen, T.; Pociot, F.; Karlsen, A. E.; Nerup, J. IL-1beta induced protein changes in diabetes prone $\mathrm{BB}$ rat islets of Langerhans identified by proteome analysis. Diabetologia 2002, 45 (11), 1550-1561.

(40) Harding, H. P.; Ron, D. Endoplasmic reticulum stress and the development of diabetes: a review. Diabetes 2002, 51 (Suppl 3), S455-S461.

(41) Fonseca, S. G.; Urano, F.; Weir, G. C.; Gromada, J.; Burcin, M. Wolfram syndrome 1 and adenylyl cyclase 8 interact at the plasma membrane to regulate insulin production and secretion. Nat. Cell Biol. 2012, 14 (10), 1105-1112.

(42) Fred, R. G.; Sandberg, M.; Pelletier, J.; Welsh, N. The human insulin mRNA is partly translated via a cap- and eIF4A-independent mechanism. Biochem. Biophys. Res. Commun. 2011, 412 (4), 693-698.

(43) Ahlemann, M.; Zeidler, R.; Lang, S.; Mack, B.; Munz, M.; Gires, O. Carcinoma-associated eIF3i overexpression facilitates mTORdependent growth transformation. Mol. Carcinog. 2006, 45 (12), 957-67.

(44) Johannesen, J.; Pie, A.; Karlsen, A. E.; Larsen, Z. M.; Jensen, A.; Vissing, H.; Kristiansen, O. P.; Pociot, F.; Nerup, J. Is mortalin a candidate gene for T1DM ? Autoimmunity 2004, 37 (6-7), 423-430.

(45) Thurmond, D. C.; Gonelle-Gispert, C.; Furukawa, M.; Halban, P. A.; Pessin, J. E. Glucose-stimulated insulin secretion is coupled to the interaction of actin with the t-SNARE (target membrane soluble $\mathrm{N}$-ethylmaleimide-sensitive factor attachment protein receptor protein) complex. Mol. Endocrinol. 2003, 17 (4), 732-742.

(46) Rondas, D.; Tomas, A.; Soto-Ribeiro, M.; Wehrle-Haller, B.; Halban, P. A. Novel mechanistic link between focal adhesion remodeling and glucose-stimulated insulin secretion. J. Biol. Chem. 2012, 287 (4), 2423-2436.

(47) Poukkula, M.; Kremneva, E.; Serlachius, M.; Lappalainen, P. Actin-depolymerizing factor homology domain: a conserved fold performing diverse roles in cytoskeletal dynamics. Cytoskeleton 2011, 68 (9), 471-490.

(48) Chiu, T. T.; Patel, N.; Shaw, A. E.; Bamburg, J. R.; Klip, A. Arp2/3- and cofilin-coordinated actin dynamics is required for insulinmediated GLUT4 translocation to the surface of muscle cells. Mol. Biol. Cell 2010, 21 (20), 3529-3539.

(49) Cooper, J. A.; Schafer, D. A. Control of actin assembly and disassembly at filament ends. Curr. Opin. Cell Biol. 2000, 12 (1), 97103

(50) Weber, A.; Pennise, C. R; Babcock, G. G.; Fowler, V. M. Tropomodulin caps the pointed ends of actin filaments. J. Cell Biol. 1994, 127 (6 Pt 1), 1627-1635.

(51) Rabinovitch, A.; Suarez-Pinzon, W. L.; Strynadka, K.; Lakey, J. R.; Rajotte, R. V. Human pancreatic islet beta-cell destruction by cytokines involves oxygen free radicals and aldehyde production. $J$. Clin. Endocrinol. Metab. 1996, 81 (9), 3197-3202.

(52) Kibbey, R. G.; Pongratz, R. L.; Romanelli, A. J.; Wollheim, C. B.; Cline, G. W.; Shulman, G. I. Mitochondrial GTP regulates glucosestimulated insulin secretion. Cell Metab. 2007, 5 (4), 253-264.

(53) Srinivasan, M.; Choi, C. S.; Ghoshal, P.; Pliss, L.; Pandya, J. D.; Hill, D.; Cline, G.; Patel, M. S. ss-Cell-specific pyruvate dehydrogenase deficiency impairs glucose-stimulated insulin secretion. Am. J. Physiol.: Endocrinol. Metab. 2010, 299 (6), E910-E917. 
(54) Mueller, C. M.; Zhang, H.; Zenilman, M. E. Pancreatic reg I binds MKP-1 and regulates cyclin D in pancreatic-derived cells. J. Surg. Res. 2008, 150 (1), 137-143.

(55) De Leon, D. D.; Farzad, C.; Crutchlow, M. F.; Brestelli, J.; Tobias, J.; Kaestner, K. H.; Stoffers, D. A. Identification of transcriptional targets during pancreatic growth after partial pancreatectomy and exendin-4 treatment. Physiol. Genomics 2006, 24 (2), 133-143.

(56) Planas, R.; Alba, A.; Carrillo, J.; Puertas, M. C.; Ampudia, R.; Pastor, X.; Okamoto, H.; Takasawa, S.; Gurr, W.; Pujol-Borrell, R.; Verdaguer, J.; Vives-Pi, M. Reg (regenerating) gene overexpression in islets from non-obese diabetic mice with accelerated diabetes: role of IFNbeta. Diabetologia 2006, 49 (10), 2379-2387. 